UDC 94(47+57)“1917”:323.272

Submitted: 09.01.2019

LBC 63.3(2)611-283.31

Accepted: 25.04.2019

\title{
THE GREAT RUSSIAN REVOLUTION AND PRACTICES OF MODERNIZATION THROUGH THE PRISM OF “COSSACK WORLD” DEVELOPMENT ${ }^{1}$
}

\author{
Sergey A. Pankratov \\ Volgograd State University, Volgograd, Russian Federation
}

\begin{abstract}
Introduction. There is a scientific, theoretical and practical necessity to understand modern phenomena of revolution and modernization. The political analysis of the influence of revolutionary events and modernization changes on the development of the Cossacks, not only as an ethnic community and social group, but as a kind of "world" that is currently undergoing a revival process, is of particular interest. Methods and materials. The paper relies on theoretical conclusions of researchers who specialize in the field of the theory of social change and development, political transitology, global studies, ensuring national and global security. Analysis. This paper presents the scientific analysis of socio-political practices of transformation of the Russian state and society in the historical perspective. The interrelation between the revolutionary events in Russia at the beginning of the $20^{\text {th }}$ century and the contemporary stage of the national modernization are traced. The author interprets the results of a survey devoted to public opinion of Russians regarding the causes and significance of the revolutionary process of 1917. The paper is focused on the correlation between "revolution" and "modernization" phenomena in the context of setting and achieving goals, tasks, using various technologies of social change. Results. The author characterizes the influence of modernization transformations on life activities of the ethnic community- the Cossacks. The article identifies the problematic aspects of the Cossacks "revival" at the present stage of the socio-political modernization of Russia. The author proposes the integrative concept of the etatist model of the political modernization of Russia considering the parameters of stable and safe development.
\end{abstract}

Key words: socio-political changes, revolution, modernization, Russia, state, Cossacks, ethnic group.

Citation. Pankratov S.A. The Great Russian Revolution and Practices of Modernization Through the Prism of "Cossack World" Development. Vestnik Volgogradskogo gosudarstvennogo universiteta. Seriya 4. Istoriya. Regionovedenie. Mezhdunarodnye otnosheniya [Science Journal of Volgograd State University. History. Area Studies. International Relations], 2019, vol. 24, no. 4, pp. 93-101. DOI: https://doi.org/10.15688/jvolsu4.2019.4.8

УДК 94(47+57)“1917”:323.272

Дата поступления статьи: 09.01.2019

ББК 63.3(2)611-283.31

Дата принятия статьи: 25.04.2019

\section{ВЕЛИКАЯ РУССКАЯ РЕВОЛЮЦИЯ И ПРАКТИКИ МОДЕРНИЗАЦИИ СКВОЗЬ ПРИЗМУ РАЗВИТИЯ «КАЗАЧЬЕГО МИРА» ${ }^{1}$}

\author{
Сергей Анатольевич Панкратов \\ Волгоградский государственный университет, г. Волгоград, Российская Федерация
}

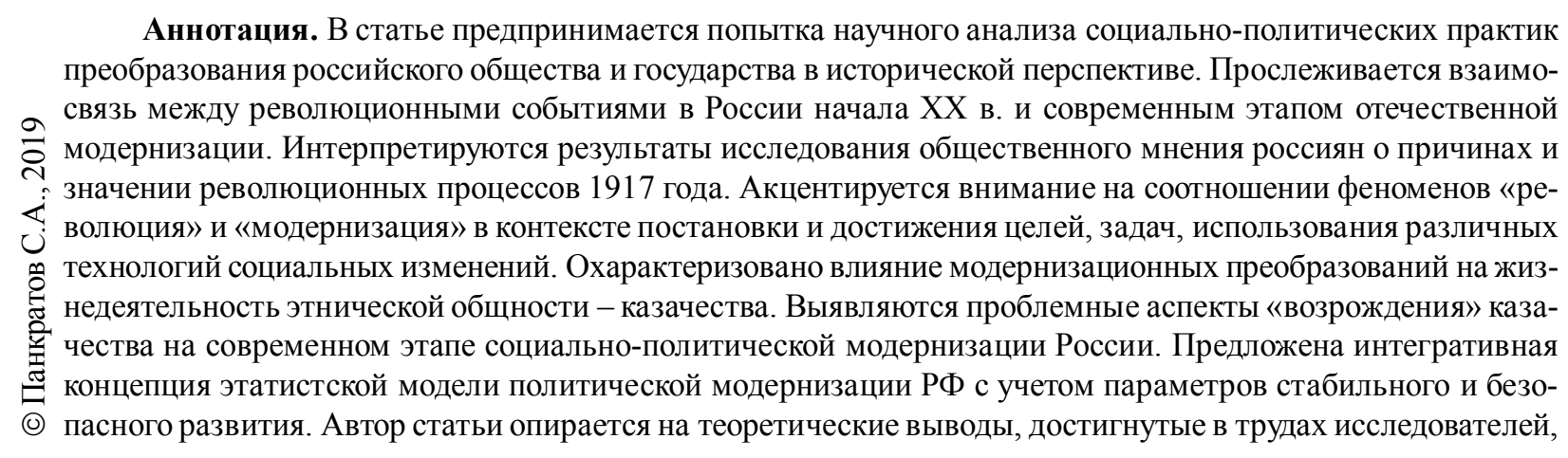


которые специализируются в области теории социальных изменений и развития, политической транзитологии, глобалистики, обеспечения национальной и глобальной безопасности.

Ключевые слова: социально-политические изменения, революция, модернизация, Россия, государство, казачество, этнос.

Цитирование. Панкратов С. А. Великая русская революция и практики модернизации сквозь призму развития «Казачьего мира» // Вестник Волгоградского государственного университета. Серия 4, История. Регионоведение. Международные отношения. - 2019. - Т. 24, № 4. - С. 93-101. - (На англ. яз.). - DOI: https:// doi.org/10.15688/jvolsu4.2019.4.8

Introduction. In the second decade of the $21^{\text {th }}$ century there is a number of anniversaries of significant events in Russian history that bring up the issue of scientific, social and political reconsideration of the content of the present stage development of the Russian society and state. One of them is the $100^{\text {th }}$ anniversary of participation of Russia in the World War I (1914-1918). Only now, hundred years later after its beginning, we have suddenly begun to realize again the sense and value of this "forgotten Great war". And it is not at all about its political and social consequences (though not everything here is as unambiguous, as it seems!), but it is rather about those incentive reasons which have forced tens of millions of people in the different parts of the globe to rush to the ruthless abyss of bloody battles, applying at the same time the most fanatic, and often brutal ways of fighting against the opponent [29, p. 4].

Certainly, the $100^{\text {th }}$ anniversary of the Great Russian Revolution is also one of those dates. According to the director of the Institute of World History of the Russian Academy of Sciences A. Chubaryan, the Great Russian Revolution includes both February and October events of 1917 , as well as civil war of 1918-1923. The czentennial of the February and October revolutions is, as the Russian President V.V. Putin has noted, a good reason "for looking back on the causes and nature of these revolutions in Russia. Not just historians and scholars should do this; Russian society in general needs an objective, honest and deep-reaching analysis of these events [...]. It is unacceptable to drag the grudges, anger and bitterness of the past into our life today, and in pursuit of one's own political and other interests to speculate on tragedies that concerned practically every family in Russia, no matter what side of the barricades our forebears were on. Let's remember that we are a single people, a united people, and we have only one Russia" [22].
Modern practices of realization of "color revolutions" have returned in the agenda of scientists and politicians (as it was during the era of collapse of the world colonial system): issues of expediency, correctness and efficiency of modernization of countries, incorporation of democratic values and institutes with the use of technologies of revolutionary violence and principles of revolutionary expediency. The civilizational, sociocultural perspectives of perception by representatives of various ethnic and confessional, demographic and other social groups of the true interests of modernization leading actors, who are leaning on revolutionary rhetoric and actions, has become aggravated.

In this regard, the political analysis of the influence of revolutionary events and modernization changes on the development of the Cossacks, not only as an ethnic community and social group, but as a kind of "world" that is currently undergoing a revival process is of particular interest.Thus, there is a scientific, theoretical and practical necessity to understand modern phenomena of revolution and modernization. The specificity of the political science discourse implies the analysis of revolution and modernization in regard with the variety of forms and directions of social changes at the global, regional, and national levels in general. At the same time, the contradictory socio-political processes that take place in the Russian Federation make it necessary to solve a number of the tasks connected directly with the choice of mechanisms and speed of the national and state construction, development of the integrative concept of modernization of public and state institutes.

Methodology of research. So far there is no methodological unity among researchers of revolutionary processes as in relation to the entity of the revolution phenomenon, and as to the purposes, technologies of its implementation [25]. From our point of view, within the political science 
discourse the most synthetic, complex definition was offered by Shtompka, who characterized revolution as one of the modes, displays of social changes. At the same time, "from other forms of social change, revolutions differ in five features: 1. They affect all levels and spheres of society: economy, politics, culture, social organization, everyday life of individuals. 2. In all spheres revolutionary changes have a radical, fundamental character, penetrate the foundations of the social structure and functioning of society. 3 . The changes caused by revolutions are extremely fast, they are like sudden explosions in the slow flow of the historical process. 4. For all these reasons, revolutions are the most characteristic manifestations of change; the time of their accomplishments is exclusive and, therefore, especially memorable. 5 . Revolutions cause unusual reactions among those who participated in them or witnessed them. It is an explosion of mass activity, it is enthusiasm, excitement, mood elevation, joy, optimism, hope; a sense of strength and power, of fulfilled hopes; acquiring the meaning of life and utopian visions of the near future" [26, p. 367].

In the scientific literature, the discussion about the essence and consequences of revolutionary changes, both in the past and present, has become significant again. According to the author, it is important to highlight the following main bases of the phenomenon of revolution. Firstly, the revolution is a consequence and form of developing a comprehensive socio-political and economic crisis of the state, as well as the value, ideological foundations in society, leading to disintegration of the ruling class (elite) and, as well to deepening of polarization of various population segments. Secondly, the level of conflict potential of society reaches its peak indicators (mass protests, uprisings, provocations, crime), which is objectified in the inevitability of change of state power representatives, and also the political system dismantlement. Thirdly, the new form of political regime, which is supported by the actions of leading actors of revolutionary transformations (parties, social and political movements, terrorist groups, etc.), institutionalizes. Fourthly, power-dominant functions are redistributed between different soical groups with the legal consolidation of status-role powers and dominants. Thus, revolutionary changes are always about basic transformations of state and social structures.
In the modern scientific and publicistic literature that describes the specificity of transformations in societies and states in the early $21^{\text {st }}$ century, a mixture of various forms of radical transformations, which were considered by V.I. Lenin, takes place quite often [16]. In particular, there is no difference between "social revolution" and "political revolution" concepts. Thus, Ralf Dahrendorf's opinion that "deep change, the transformation of core structures of a society which in the nature of the case takes some time" and a "political revolution" is a "quick change, notably the circulation of those at the top within days or months by highly visible, often violent action" [6, p. 16] proves it. It is especially significant in the analysis of the socalled "color revolutions", that define the content of contemporary political globalization of the world community [2].

Analysis. Revolution and modernization relation. We cannot but agree with the position of Eisenstadt, who emphasizes the multilateral character of the results of revolutionary changes and their relationship to the modernization process: forcible change of the existing political regime, disruption of the factors of its legitimacy; change of the ruling political elite; implementation of changes "in economic (capitalist or socialist) development, in political modernization (especially centralization and some type of democratization), and in far-reaching social changes with potentially emancipatory results"; a radical break with the past in the framework of the extreme ideologization of the consciousness and practices of the behavior of the participants in the revolution; the formation of a "new man" on the principles of revolutionary morality [8].

Samuel Huntington emphasizes the diversity of the relationship between revolutionary and modernization processes in various civilizational models. Thus, in the "Western" model, the political institutions of the old regime are first crushed, and then followed by the mobilization of new groups in politics and then the creation of new political institutions. "Eastern" revolution, on the contrary, begins with the mobilization of new groups in politics and the creation of new political institutions and ends with the violent overthrow of the political institutions of the old system. Moreover, in the "Western" revolution, a fierce struggle unfolds between the moderate and radical sides of the 
transformations. In the "Eastern" revolution, the revolutionaries and the government are fighting $[10$, p. 46].

In this regard, it is important to note that the emergence of the modernization paradigm is associated with a number of historical and political processes of the last three centuries that led to radical changes in the "established" structures of social life, as well as the need for conceptual reflection on the old and new type of social organization. The modernization theory used ideal types of traditional and modern society as methodological tools, which are methodological vectors that reveal the logic, mechanisms and trajectories of social (political) changes. Modernization points to the radical nature of the transformation of the former institutional, mental and other structures into other forms that are more adequate to reality and, as a consequence, the emergence of a "social price" for approaching the desired goal.

From our point of view, it is important to emphasize that the opposition of tradition and modernity is of purely methodological significance. In fact, we should speak more about quantitative differences in the prevalence of traditions and innovations in the structure of certain societies. In this way, "The main idea of modernization is that economic and technological progress generates a complex of socio-political transformations, and they, as a rule, lead to radical changes in values and motivation. This includes changing the role of religion, career aspirations, fertility, gender roles, sexual norms. These changes also determine the massive demand for democratic institutions and the tightening of demands for elites. As a result, democracy is becoming more and more probable, and war is becoming less acceptable to the people" [12, p. 166-167].

It should immediately be stipulated that a significant part of the former and current researchers are skeptical about the revolutionary technologies of social modernization. As Nikolay Berdyaev notes, "never, in fact, did any of the revolutions succeed within the confines of history, because if revolutions were an important moment in the fate of peoples, a moment inherently inevitable, to which all the preceding fate led and its further fulfillment, they never resolved Those tasks that were assigned to him - never it was and never will be [...]. Usually what people expected and sought was not achieved at all. Ordinarily, revolutions ended in a reaction in which something new was revealed, in which the comprehension of the experience was taking place, even if the reactions were accompanied by a number of negative manifestations and partially thrown back by human societies" [4, p. 156].

The Great Russian Revolution and modernization transformations: a vision through the centenary. The uncertainty of public opinion about the revolutionary events of 1917 and, in general, the Soviet stage of Russia's political history, is connected with the "Gorbachev revolution" - the era of "acceleration", "glasnost", "perestroyka" characterized by an attempt to improve "real socialism", the formation of a new political thinking for the USSR and the whole world [9]. Rethinking Russian history and values, an attempt to modernize the Soviet political and economic systems resulted in a geopolitical catastrophe of the $20^{\text {th }}$ century - the disintegration of the USSR. As the President of the Russian Federation V.V. Putin acknowledged, "for the Russian people it has become a real drama. Tens of millions of our fellow citizens and compatriots were outside the Russian territory. The epidemic of disintegration has also spread in Russia itself" [23]. In the public communicative space, there are often calls "to judge Gorbachev" for betraying the interests of the country [18].

According to a survey conducted by the Levada-Center in 2017, $32 \%$ of respondents believe that the February Revolution was a stage on the road to the Great October Socialist Revolution, which created the world's first state of workers and peasants; $19 \%$ expressed the opinion that the February revolution weakened Russia, which led to the October coup and the collapse of the country; $11 \%$ of respondents are convinced that the February Revolution, would lead Russia to the path of progress and democracy, and our country would now be among the most developed countries in the world, if October revolution did not happen; $9 \%$ are inclined to the view that the February revolution did not have a significant role in the history of Russia and $30 \%$ could not define their attitude towards the February revolution of the year 1917 [19].

The famous writer Aleksander Solzhenitsyn asks, "So, should what happened in February be called the revolution? - If we consider the 
revolution as sudden, violent and with the participation of the masses a change in the political structure of the state? We call three revolutions: 1905, February 1917 and October. But in 1905-1906 there were no significant changes in the state and people's lives, and there was no movement of millions of people: there was a SIMULATION OF THE REVOLUTION, there was much scattered terror (and criminal) when revolutionaries (and criminals) and intellectuals pushed, pushed, swung, - but it did not swing and did not swing. And February - even implausible: the country's drowsiness, insignificant participation of the masses - and no resistance to power. And October is a short, rough local military coup according to plan, what kind of revolution is there? None seems to fit in the revolution concept. The latter two are quite accurately called coups. But there is no doubt that in the $20^{\text {th }}$ century the greatest bloody irreversible revolution of universal significance occurred in Russia. The only irreversibility and radical change is the revolution" [27, p. 20].

The results of the Russian national survey carried out by the Levada-Center in 2017 show that $23 \%$ of respondents believe that V.I. Lenin "brought our country to the path of progress and justice" through the October Revolution of 1917; $19 \%$ defend the view that the leader of the world proletariat "tried to rely on the best intentions and hopes of people to lead them to a brighter future"; $15 \%$ hold the opinion that V.I. Lenin "led our country along the wrong path, and this caused many misfortunes and troubles"; $11 \%$ say that "Lenin was mistaken in his expectations about revolution and communism"; $7 \%$ are inclined to the view that "Lenin was a cruel man who, with the help of violence, tried to transform the country". At the same time, the attitude to what happened in the country after the death of V.I. Lenin - the continuation of the revolution or the evasion of its principles and ideals - was distributed as follows: $30 \%$ believed that this was the continuation of the revolution; $43 \%$ - this was the evasion of its principles and ideals; $27 \%-$ could not give an answer [20].

In one of his program papers on the causes of the Soviet failure of the "Marxist experiment in Russia" Bzhezinskiy wrote, "It was a Western doctrine, developed in the reading room of the British Museum by an intellectual, a German Jew.
Then this foreign plant was transplanted into a distant Eurasian empire with the traditions of semieastern despotism - it was transplanted by a single author of pamphlets, a Russian revolutionary who acted as a history surgeon. What happened in Russia after the Bolshevik revolution should not have surprised anyone who had carefully read Vladimir Ilyich Lenin" [5, p. 256].

At the same time it is obvious, that the process of modernization transformations and revolutionary events in Russia in the $20^{\text {th }}$ century is not so unambiguous and has its own historical causes.

From our point of view, the October Revolution of 1917 really revealed two objective trends in the development of the country. The first of them is the evolutionary development of society along the "civilized", standard-western way of modernization. As the leading force capable of directing Russia to such a path was the domestic liberal bourgeoisie. The second one was the inevitability of a social explosion and further development, determined by the logic of this explosion. For Russia, the issue of choosing the path was decided by the specific balance of political and class powers, as well as by the fact that social, economic, political, and international contradictions intensified and hardly could be solved in any other way than the people's revolution [3]. The October Revolution of 1917, in the broadest general historical sense of the word, was the result of the previous inefficient model of modernization development [21].

"Cossack World" in the context of the diversity of national modernization vectors. The contradictory stages of the national modernization of society and the state are fully reflected in the life activity of entire nations and social strata, including the Cossacks. In modern scientific literature, one of the dominant points of view was to characterize the Cossacks not only as an ethnic community, but as a certain original "world" that reached its highest maturity in the $14^{\text {th }}-18^{\text {th }}$ centuries. According to A.V. Sopov, it was during this period that the Cossacks became "a military-democratic society, the Cossack troops were warrior communities, forming a single caste, performing a specific function that is handed on, meaning a special class of professional warriors began to form" [28]. At the same time, the Cossacks should be identified as an integral part 
of the Russian people, whose stratification acted as the backbone of the statehood of the Russian Empire [13].

However, with the abolition of the serfdom law and the beginning of Alexander II's modernization reforms, aimed primarily at the liberal-bourgeois transformation of the existing structure, the internal foundations of the Cossack life were distorted. As noted by N.B. Akoeva, streams of the non-Cossack population flooded into the Southern region bringing in their culture, assimilating ethnic culture, traditions, way of life of the "Cossack society", distant tendencies between the Don, Kuban, Terek Cossacks had appeared. The passion for wealth accumulation, mercantilism and pragmatism intensified, private property became the central value, social stratification progressed: the Cossack fraternity was divided into the prosperous and poor Cossacks; hired labor and the unprecedented phenomenon of Cossack farm laborers emerged among the Cossacks. "The Cossack experienced a psychological, mental rupture with one's own value attitudes" [1].

In this article, we only point out the effect of modernization on the particular estate, which had to experience the tragedy of the revolutionary events, of the civil war of 1917-1923. In the historical and political literature, the approaches of the young Soviet government to the Cossacks, especially in the South of Russia, are described in sufficient detail: from the elimination of the Cossack autonomy to the cautious economic policy that does not sharply affect the vital interests of middle peasants [7]. There are still debates about compulsion and justification of the cardinal change of the vectors of the Russian state relations. In September 1918, the Decree of the Council of People's Commissars on establishing the Soviet Don Army and granting broad autonomy to the Cossacks was adopted. But already on January 29, 1919, a circular letter was issued - a directive of the Organizing Bureau of the Central Committee of the Russian Communist Party of Bolsheviks about "decossackization". Only after the Red Army left the territory of the Don army, the fallacy of the "decossackization" policy was recognized. In 1936, an active state campaign "facing the Cossacks" was launched, bearing the historical-folklore and decorative character of "pseudo-apologetics". From our point of view, there were objective and subjective factors that determined the polarization of positions in relation to certain segments of the Russian population, in this case, the Cossacks.

Thus, the Russian version of modernization and revolution are neither a complete chaos, nor a transition to a more just society.

Revival of the Cossacks or the "game in dressed up men"? With the beginning of "perestroyka" of M.S. Gorbachev and especially after the collapse of the USSR, the revival of the Cossacks intensified. There is a "steady growth in the number and size of Cossack communities", in particular, the Don Cossack Host, "as well as an increase in the proportion of Cossacks in selfgovernment bodies and the local administration of southern Russia, which already allows us to speak of the Cossacks as a serious social and political force in the region" [14]. However, a number of authors again indicate either the imitative nature of this process or the deformation of life traditions and foundations. As noted, "the revival of neo class estate led to the division of the Cossacks into the registered and the public to the split of the Cossack movement. The revival of neo class estate can go along the path of the absorption of the ethnos, people and cultural tradition of the Cossacks - by pseudo class estate, invented by liberal reformers. The form of the pseudo class estate service of the Cossacks can turn the Cossacks into a profession, tearing it out of the depths of the original culture". But can it be otherwise at the present stage of modernization? It should be recognized that the archetype of the political culture of a large part of the Russian citizens still contains elements of both pre-revolutionary and Soviet monarchism, as well as the current practice of functioning of the vertical of power - the President's manual management. In this regard, "the revived neo class estate can turn for the Cossacks to the transformation of the spiritual principle of military service to God, the Tsar and the Homeland - into military professionalism that stands outside the Cossack tradition" [14].

In search of the optimal model of modernization of the Russian Federation. We think that today the etatist model of Russia's modernization is the most effective one. In the frame of this model the leading and organizing role of the state is considered. It is based on the 
"general code of development" of a "strong state" developed throughout the history of Russia. As Ilyin states, "by the power of the flat space, by the strength of the national temperament, by the strength of Slavic individualism and by the weakness of its social discipline - the Russian people are placed in conditions that require not a weak but a strong state center [...]. The Russian person is able to maintain order and build the state; he is able to maintain exemplary discipline, sacrificially serve and die for his homeland. But this ability manifests itself and bears fruit [...] when it is brought to life, fixed and conducted by the one who impresses him, strong and worthy of state authority" [11, p. 280].

It is important to emphasize that the etatist model of modernization presupposes simultaneous structural and functional modernization of the Russian state. That should also contribute to the process of institutionalization of public policy, which is understood as the partnership of the government and civil society. It makes sense to generally define public policy as "an activity characterized by a systemic interaction of the state, business, non-profit community, diverse social, professional groups, public associations about the realization of personal and public interests, production, distribution and use of public resources and benefits, while taking into account the will of the people and the population of certain territories" [17, p. 45].

At the present time, it is possible to observe the elements of the theoretical construction of the "spiral of silence", justified by the German sociologist Elizabeth Noel-Neumann in the social practice of protest behavior. "Loud" - an aggressive minority often puts pressure on a poorly organized majority. A subculture of violence and provocation is being formed, especially in the youth environment. Social networks are not just communication channels, but technologies of socialization of uncompromising attitude to many important social issues. If in 1991 the mobilizing thesis was "Away with Article 6 that gives monopoly to the Communist Party of the Soviet Union (CPSU)", in 2011 - "Give fair elections", then in 2017 - "We are against corruption". Populist demands are doubtless protest ones, and they do not program positive activities for a period after the government is disorganized and overthrown. Thus, under the pretext of activating civic initiatives, in the context of contradictory and difficult modernization reforms an attempt to institutionalize the elements of the "color revolution" is actually made.

Results. Modern political studies of the relationship of the Great Russian Revolution and the processes of modernization through the prism of the fate of specific social and ethnic groups are at the initial stage of understanding. As, within the framework of historical science, extensive material has been accumulated, political scientists face the task of identifying interconnections and uncovering trends in the influence of revolutionary and evolutionary transformation processes on political culture and social and political practices of specific social classes and groups at various stages of Russia's modernization [24]. In this work, we come to the conclusion that the adoption of modern values inevitably leads to the "painful" breakdown of traditional ways of life among the Cossacks, both in economic practices and the social and political structure of the "Cossack world". At the same time, the "revival of the Cossacks" after the collapse of the USSR can be viewed as a process of remodernization, characterized by the change in the "aggiornamanento" vector.

The statement that the democratic institutions are incompatible with the Russian political tradition is theoretically false and practically dangerous. This idea blocks the creation of democratic bodies or facilitates liquidation, because of their "dissimilarity" to foreign liberal models. Modernization of Russian society and the state is not their Westernization. The state's impact on society consists primarily in accumulating and upholding the fundamental values of this society, the development of harmonization procedures and mechanisms for the coexistence of various interests in the context of their pluralization [15].

At the same time, there are risks and dangers at present time that are connected with promoting the republican democratic tradition in Russia in a revolutionary way, while preserving faith in a good charismatic leader of the country. From our point of view, it is important to break the vicious circle of the split between the ruling elite and the majority of the population. It leads to the protest movement that with the use of modern communication technologies can revolutionize the practices of life improvement and allow for coming to power of the elite new generation representatives. 
Thus, for developing and implementing the principles for promoting the interconnection of the federal center and regions, modernization of the political system of the Russian Federation, it is necessary to take into account the tendencies of the contradictory impact of modernization on the Cossacks, when engaging it to support and protect the state system at the previous and current stages of Russia's development.

\section{NOTE}

${ }^{1}$ The reported study was supportet by the Russian Foundation for Basic Research (RFBR) and the Volgograd Region Administration in the framework of research project no. 19-411-340006 p_a "Socio-Political Design of Public Space and Mass Communication System in the Regions of the Russian Federation (The Example of the Volgograd Region)".

\section{REFERENCES}

1. Akoeva N.B. Vliyanie modernizatsionnykh protsessov na povsednevnuyu zhizn kazachyego naseleniya Yuga Rossii vo vtoroy polovine XIX nachale $X X v v$.: avtoref. dis. d-ra ist. nauk [Impact of Modernization Processes on the Everyday Life of the Cossack Population of Southern Russia in the Late $19^{\text {th }}-$ Early $20^{\text {th }}$ c. Dr. hist. sci. abs. diss.]. Maykop, 2012.38 p.

2. Avanchenko A.B., ed. Chto nado znat o "tsvetnykh revolyutsiyakh» [What You Need to Know About "Color Revolutions"]. Moscow, MPGU, 2016. $136 \mathrm{p}$.

3. Berdyaev N.A. Istoki i smysl russkogo kommunizma [Origins and Meaning of Russian Communism]. Moscow, Nauka Publ., 1990. 220 p.

4. Berdyaev N.A. Smysl istorii [Meaning of History]. Moscow, Mysl Publ., 1990. 176 p.

5. Bzhezinskiy Z. «Bolshoy proval. Agoniya kommunizma» [Big Failure. Agony of Communism]. Kvintessentsiya: Filosofskiy almanakh [Quintessence. Philosophical Almanac]. Moscow, Politizdat, 1990. 447 p.

6. DahrendorfR. The Modern Social Conflict: An Essay on the Politics of Liberty. Berkeley, Los Angeles, University of California Press, $2002.289 \mathrm{p}$.

7. Dolgov K.E. Bolsheviki i Donskoe kazachestvo v 1918-1920 gg. [The Bolsheviks and the Don Cossacks in 1918-1920]. Izvestiya Rossiyskogo gosudarstvennogo pedagogicheskogo universiteta im. A.I. Gertsena: Obshchestvennye i gumanitarnye nauki [Izvestia: Herzen University Journal of Humanities \& Science], 2008, no. 1, pp. 164-170.
8. Eisenstadt S.N. Revolution and the Transformation of Societies: A Comparative Study of Civilizations. New York, Free Press, 1978. 416 p.

9. Gorbachev M.S. Perestroyka i novoe myshlenie dlya nashey strany i dlya vsego mira [Perestroyka and New Thinking for Our Country and for the Whole World]. Moscow, Politizdat, 1989. $270 \mathrm{p}$.

10. Huntington S.P. Political Order in Changing Societies. New Haven, Yale University Press, $1973.480 \mathrm{p}$.

11. Ilyin I.A. O silnoy vlasti [About Strong Power]. O gryadushchey Rossii: izbrannye statyi [On the Upcoming Russia. Selected Articles]. Moscow, Voenizdat, $1993.368 \mathrm{p}$.

12. InglhartR. 2010. Modernizatsiya i demokratiya [Modernization and Democracy]. Inozemtseva V.L., ed. Demokratiya i modernizatsiya: $k$ diskussii o vyzovakh $X X I$ veka [Democracy and Modernization. To the Discussion on the Challenges of the $21^{\text {st }}$ c.]. Moscow, Evropa Publ., 2010, pp. 163- 182.

13. Kapustina (Artamonova) M.G. Upravlenie protsessami vozrozhdeniya kazachestva $\mathrm{v}$ usloviyakh modernizatsii obshchestva [Management of the Revival Processes of the Cossacks in the Context of Modernization of Society]. Uroven zhizni naseleniya regionov Rossii [Living Standard of the Population of Russian Regions], 2017, no. 3, pp. 111-116.

14. Kozlovskiy V.V., Kudryakov I.O. Faktory i tendentsii razvitiya Donskogo kazachestva [Factors and Trends of Development of the Don Cossacks]. Sotsiologicheskie issledovaniya [Sociological Studies], 2014, no. 10, pp. 45-49.

15. Kozhokin E.M. Zakonchilas li Velikaya russkaya revolyutsiya [Has the Great Russian Revolution Ended?]. Politicheskie issledovaniya [Political Studies], 2017, no. 6, pp. 109-124.

16. Oyzerman T.I., Kosolapov R.I., Egorov A.G. et. al., eds. Lenin. Filosofiya. Sovremennost [Lenin. Philosophy. Modernity]. Moscow, Politizdat, 1985.447 p.

17. Mikheev V.A. Publichnaya politika v sovremennoy Rossii [Public Policy in Modern Russia]. Vlast [Vlast], 2005, no. 4, p. 45.

18. Nesmotrya na osuzhdenie i proklyatiya so storony mnogikh sootechestvennikov, Mikhailu Gorbachevu po-prezhnemu est chto skazat [Despite Condemnation and Curses of Many Compatriots, Mikhail Gorbachev Still Has Something to Say]. URL: http://geo-politica.info/nesmotrya-na-osuzhdenie-iproklyatiya-so-storony-mnogikh-sootechestvennikovmikhailu-gorbachevu-po-p.html (accessed 15 November 2018).

19. Opros Levada Tsentra: Fevralskaya revolyutsiya 1917 goda [Levada Center's Survey: February Revolution of 1917]. URL: http://www.levada. ru/2017/02/14/fevralskaya-revolyutsiya-1917/ (accessed 15 November 2018). 
20. Opros Levada Tsentra: V.I. Lenin [Levada Center's Survey: V.I. Lenin]. URL: http:// www.levada. ru/2017/04/19/vladimir-lenin/ (accessed 23 November 2018).

21. Pankratov S.A. Politicheskaya modernizatsiya $v$ Rossii $v$ kontekste ustoychivogo razvitiya (Teoreticheskiy aspekt): dis. d-ra polit. nauk [Political Modernization in Russia in the Context of Sustainable Development (Theoretical Aspect). Dr. polit. sci. diss.]. Krasnodar, 2006. 395p.

22. Putin V.V. Poslanie Prezidenta RF Federalnomu sobraniyu Rossii 1 dekabrya 2016 goda [Message from the President of the Russian Federation to the Federal Assembly of Russia on December 1, 2016]. 2016. URL: http://www.kremlin.ru/events/president/ news/53379 (accessed 14 November 2018).

23. Putin V.V. Poslanie Prezidenta $R F$ Federalnomu sobraniyu Rossii 25 aprelya 2005 goda [Message from the President of the Russian Federation to the Federal Assembly of Russia on April 25, 2005]. 2005. URL: http://www.kremlin.ru/events/president/ transcripts/22931 (accessed 14 November 2018).

24. Rozov N.S. Krizis i revolyutsiya: polya vzaimodeystviya, strategii aktorov i traektorii konfliktnoy dinamiki [Crisis and Revolution: Fields of Interaction, Actors' Strategies and Trajectories of Conflict Dynamics]. Politicheskie issledovaniya [Political Studies], 2017, no. 6, pp. 92-108.

25. Shults E.E. Teoriya revolyutsii: Revolyutsii $i$ sovremennye tsivilizatsii [Revolution Theory: Revolutions and Modern Civilizations]. Moscow, LENAND Publ., 2017. 400 p.

26. Shtompka P. Sotsiologiya sotsialnykh izmeneniy [Sociology of Social Changes]. Moscow, Aspekt Press, 1996. 414 p.

27. Solzhenitsyn A.I. Razmyshleniya nad Fevralskoy revolyutsiey [Reflections on the February Revolution]. Rodina. Special Issues, 2017, pp. 2-24.

28. Sopov A.V. Dinamika sotsialnopoliticheskogo $i$ etnokulturnogo statusa kazachestva: avtoref. dis. ... d-ra ist. nauk [Dynamics of the Socio-Political and Ethno-Cultural Status of the Cossacks. Dr. hist. sci. abs. diss.]. Moscow, 2012. 68 p.

29. Sorokin A.K., Shutov A.Yu., Anderson K.M., eds. Rossiya v Velikoy voyne 1914-1918 godov. Obrazy i teksty [Russia in the Great War of 1914-1918. Images and Texts]. Moscow, Politicheskaya entsiklopediya Publ., 2014. 279 p.

\section{Information about the Author}

Sergey A. Pankratov, Doctor of Sciences (Politics), Professor, Head of the Department of International Relations, Political Science and Area Studies, Volgograd State University, Prosp. Universitetsky, 100, 400062 Volgograd, Russian Federation, pankratov@volsu.ru, https://orcid.org/0000-0002-1733-730X

\section{Информация об авторе}

Сергей Анатольевич Панкратов, доктор политических наук, профессор, заведующий кафедрой международных отношений, политологии и регионоведения, Волгоградский государственный университет, просп. Университетский, 100, 400062 г. Волгоград, Российская Федерация, pankratov@volsu.ru, https://orcid.org/0000-0002-1733-730X 